This item was submitted to Loughborough's Research Repository by the author.

Items in Figshare are protected by copyright, with all rights reserved, unless otherwise indicated.

\title{
An unholy pilgrimage? Yasukuni and the construction of Japan's Asia imaginary
}

PLEASE CITE THE PUBLISHED VERSION

http://dx.doi.org/10.1111/j.1943-0787.2009.01101.x

\section{PUBLISHER}

Wiley (@ Policy Studies Organization)

VERSION

AM (Accepted Manuscript)

\section{PUBLISHER STATEMENT}

This work is made available according to the conditions of the Creative Commons Attribution-NonCommercialNoDerivatives 4.0 International (CC BY-NC-ND 4.0) licence. Full details of this licence are available at: https://creativecommons.org/licenses/by-nc-nd/4.0/

\section{LICENCE}

CC BY-NC-ND 4.0

\section{REPOSITORY RECORD}

Tamaki, Taku. 2019. "An Unholy Pilgrimage? Yasukuni and the Construction of Japan's Asia Imaginary". figshare. https://hdl.handle.net/2134/15871. 


\title{
An Unholy Pilgrimage? Yasukuni and the Construction of Japan's Asia Imaginary
}

Taku Tamaki, PhD

\author{
Dept. of Politics, International Relations \& European Studies \\ Loughborough University \\ Loughborough \\ Leicestershire LE11 3TU \\ UNITED KINGDOM \\ E-mail: T.Tamaki@lboro.ac.uk
}

\section{9,916 words}

Acknowledgements: The earlier draft of this article was presented at the Institute of Asia Pacific Studies at the University of Nottingham in November 2006 and at the Research Seminar in the Department of PIRES at Loughborough University in February 2006. I am grateful to the Editor and three anonymous reviewers of the Journal, as well as Olly Daddow for helpful comments on an earlier draft. 


\title{
An Unholy Pilgrimage? Yasukuni and the Construction of Japan's Asia Imaginary
}

\begin{abstract}
Why are Japanese policy makers intent on visiting Yasukuni Shrine and keep on holding China and South Korea solely responsible for the 'politics of memory' in diplomatic relations? It is easy—and perhaps misleading — to suggest that Japan does not care about China nor South Korea; and also to argue that Japan's memory of the War is one of 'glory' rather than 'aggression'. Instead, I posit the idea that Japan's memory of the war is, indeed, traumatic; and the post-war legacy of 'democratic and peaceful' nation makes it difficult for the policy makers to adopt countenance Chinese/South Korean criticisms.
\end{abstract}

Key Words: Yasukuni Shrine; Japanese Identity; Politics of Memory; China; South Korea

Taku Tamaki is a Lecturer (Assistant Professor) in International Relations in the Department of Politics, International Relations and European Studies at Loughborough University, UK. His research interests are in International Relations Theory, the international politics of the Asia-Pacific region, and Japanese national identity construction. 


\section{An Unholy Pilgrimage? Yasukuni and the Construction of Japan's Asia Imaginary}

The adamant refusal by Japan’s former Prime Minister, Koizumi Junichiro (April 2001 to September 2006), to abstain from visiting the controversial Yasukuni Shrine in Tokyo is a stark reminder that the official Japanese memory of the wartime past is fundamentally at odds with the corresponding memories in China and South Korea. Koizumi insisted that the visits were a pilgrimage to comfort the souls of those who perished for the country during the War: that it was an 'issue of the heart' (kokoro no mondai); and that it should not matter where and how a Japanese prime minister pays homage. ${ }^{1}$ To this, the Chinese and South Korean counterparts retort that the Japanese government is whitewashing history (The Economist, 18 February 2006: 63).

Yasukuni evokes a complex web of debates over the politics of memory. On the one hand, the shrine debate exposes the unsettled and often sensitive nature of Japanese mnemonics; on the other hand, it reveals the ethnocentricity of Japanese national commemoration, such that Asian claims to their memories of suffering under Japanese colonial rule are interpreted as an intervention into Japan's domestic affairs. Japan's memory as a function of suffering and death during the War clashes with the neighbours' claims to similar pain, so much so that the remembrance of one nation's suffering necessarily becomes the forgetting of others. It is this interaction between domestic and international politics of memory which haunts Japan's relations with its neighbours.

This article explores the multiple symbolisms inherent in the Yasukuni debate by discussing how the domestic politics of memory reconstructs Japan's Asia imaginary. The focus is on the narratives by Japanese officials and other public figures, interspersed with newspaper editorials. They are, in effect, policy and identity entrepreneurs, with a realisable impact on Tokyo's diplomatic relations with its Asian neighbours. While not a comprehensive overview of Japanese mnemonics, they nonetheless play crucial roles in positing Japan's image to the outside world. The first section provides the conceptual framework within which Japan's Asia imaginary is reproduced via the public discourse on memory and the 'past'. The second section elaborates on how Japan's relationship with its neighbours needs to be construed as a 
social construction, analysing how the 'past' emerges and becomes reified into a 'difficult' issue. Section three investigates the various ways in which Yasukuni and the concomitant politics of memory became a potent force behind Japan's identity construction. The final section then analyses the various imageries evoked by the Yasukuni debate-both in terms of Japanese introspection as well as in reaction to external criticism.

My intention in this article is not to evaluate whether Yasukuni 'causes' rifts between Tokyo and its neighbours; bur rather, I explore the 'linguistic space' of Yasukuni within the policy-making circles to appreciate how the domestic debates over the shrine coalesce to reconstruct the official narratives of memory and the Asian Otherness within the Japanese establishment. At the same time, by analysing this process, we can start appreciating how the Chinese and Korean criticisms over Yasukuni are ultimately counter-productive. Furthermore, I am not going to problematise the process through which Japanese conservatives strengthened its stronghold on the political establishment, only to take this 'fact' as a starting point of analysis.

\section{The Intersubjective Sphere of Japan's Asian Diplomacy}

Yasukuni Shrine symbolises the existence of a domestic debate acting as a locus from which the remembering/forgetting dichotomy is produced, and its contemporary, collective, Asia imaginary among the policy entrepreneurs emerges. Given Koizumi's determination on the pilgrimage, it is tempting to think of the controversy as a one-off event: Abe Shinzo's premiership seems to have marked a thaw in both Sino-Japanese and Japan-South Korea diplomacy (The Economist, 7 October 2006: 29-31). Indeed, there were indications prior to his assumption of office that Abe was contemplating a more sensitive approach towards Yasukuni. Financial Times (27 July 2006: 10) reported that 'Mr Abe left open the door for a policy change on the issue of Yasukuni shrine to Japan's war dead', quoting him as saying, 'I have no intention whatsoever to make a declaration that I will go to the shrine' (ibid). In his first policy statement to the Diet in September 2006, he stressed the importance of China and South Korea, 
and that 'it is important that we can genuinely communicate in a future-oriented manner'. ${ }^{2}$

In many ways, Koizumi's refusal to countenance critics—both inside and outside — signifies that he did not occupy a social vacuum; and that it was very much integral to the emergence of Japan's Asia imaginary within the conservative establishment. Sata Genichiro, the minister in charge of fiscal reform, stated that, 'I feel if is appropriate to pay tribute to those who became the basis for today's peaceful Japan'; while Takaichi Sanae, the minister responsible for demographics noted that, 'I have always visited the shrine. I would like to continue paying respect to those who perished in their line of duty'. The Minister for Internal Affairs and Communications, Suga Yoshihide, argued that 'it is natural for me, even as a cabinet member, to pay tribute to the war dead'. ${ }^{3}$ It is tempting to dismiss these narratives as merely unrepentant right wing musings. Yet, it is also the case that they constitute a larger linguistic sphere that seeks to foreclose domestic contestations and present a certain version of memory as a dominant narrative to the outside world. Yamanouchi Masayuki (2005: 12) of Tokyo University bemoans the lack of admission by China that Class A War Criminals were also responsible for the deaths of 3.5 million Japanese war-dead. These narratives occupy an intersubjective sphere within which Japanese memory construction translates into its Asia imaginary.

Yasukuni still poses itself as a locus of debate as well as a poignant symbol of the past as a lesson in re-articulating Japan's post-war peace identity. That the wider policy elites seem to engage in the debate suggests that Koizumi was part of the emergent dominant Japanese narrative of Self in opposition to the Asian Other, rather than a mere anomaly. Given the recurring nature of Yasukuni controversy and Koizumi's popularity, his pledge to pay homage is a reflection of how the political establishment utilises Yasukuni as a symbol of Japan’s predicament. ${ }^{4}$ Pace Benedict Anderson (1991), the dominant narrative of Japanese Self is constructed in opposition to the Asian Other via the particular 'language' of remembering/forgetting. The political establishment plays a crucial part in propagating a linguistic sphere within which a dominant narrative emerges and Asia imaginary is elaborated. As Rogers Brubaker and Frederick Cooper (2000: 14) argue, identity as a 'categorisation' 'invites us to specify the agents that do the identifying' - in other words, the identity entrepreneurs who forge an emergent collective solidarity. The Yasukuni debate enshrines the dichotomy inherent within the larger narrative of Japan's memory- and 
identity construction. Yasukuni acts as a symbol of remembering the sufferings of the nation during the War-both in terms of material hardships and the vagaries of militarism-and forgetting the existence of Asia. The notion that everybody suffered under imperialism is enough to focus national attention towards Japan's suffering, and away from the memories of sufferings among the Asians (see Dower, 1999). Such conflation of sufferings - and the easy identification of wartime military clique as culprits—re-ignites Asian criticisms of Tokyo’s purported whitewashing of history and the resultant Japanese backlash (see Kim, 1995; Minear, 1971). The process of remembering generates a countervailing force of forgetfulness that is biased in favour of prioritising the experiences of Self over the Others. As Rafael Narvaez (2006: 66) argues, '[c]ollective memory is not only about remembering (the past) or about social order and action (the present), but critically, it is about how social groups project themselves toward the future'.

The domestic contest over its own past; how it should be remembered; and what needs to be forgotten, all reveal the multiplitude of mnemonics. Whatever the claims of both the Right and Left, remembering/forgetting is manifested within the politics of memory as countervailing narratives (see Ueno, 2005). However, in order for this politics of memory to be played out, a common platform is needed; and in the case of Yasukuni controversy, the common realm is provided by the Otherness of Asia with which Japan could never reconcile itself. While not blindly following the myth of Japanese uniqueness, it is my argument that the elaborating of this myth over the centuries has facilitated the emergence and elaboration of Japan's self image as both non-western and non-Asian (Tamaki, 2003). Coupled with Japan's modernisation from the end of the $19^{\text {th }}$ century onwards, the purported distinction between the 'superior and modern' Japan and the 'backward' Asia became more 'evident' in the eyes of Japanese identity entrepreneurs, so much so that the narrative of uniqueness has been reified into a 'reality’ (see Yeun, 1997; Miyoshi, 1991).

Identity is oppositional; and is often contested both within and without the community (Narvaez, 2006: 64). Yet, faced with an external denial of legitimacy, the 'problem' of Yasukuni emerges as an inherently 'Japanese problem'. Maruyama Masao (1964: 166) suggests that the post-war peace state identity counteracts the psychological vacuum created from the trauma of defeat (seishin-teki shinku), but fails to fully expunge the pre-war Asia imaginary. For Maruyama, pre-war nationalism did not disappear nor change; it was atomised and dissipated (ibid: 167). 
While Koizumi might have been an astute identity entrepreneur, this position can only be achieved when he himself is very much part of the social process. As Margaret Archer (1995: 255-56) argues,

The particular social identities of individual social actors are forged from agential collectivities in relation to the array of organizational roles which are available in society at that specific point in time.

Koizumi's narratives as part of the social reproduction provide an impetus for the emergence and elaboration of Yasukuni as a dominant mnemonic; and the debates surrounding them take on a life of their own to become an intersubjective sphere within which the Asia imaginary is reconstructed. ${ }^{5}$ Despite the inner contradictions over the prescriptions for Yasukuni, the domestic debates reproduce collective Japanese memory against which criticisms from both China and South Korea are interpreted. It is this logic of collective action (Olson, 1965) that lies at the heart of Tokyo’s Asia diplomacy.

The clash of memories between Tokyo, on the one hand; and Beijing and Seoul, on the other, is also an institutional fact within which Tokyo perceives its Asia diplomacy to be 'difficult' and 'awkward'. As Drifte (1998: 26) notes, there is a

Regional understanding that what Japan did to other Asian countries until 1945 was wrong (either morally and/or tactically) and that it should never be repeated, This recognition of historical debt, as insufficient as this recognition may appear to be to many neighbours of Japan, restrains Japan in exerting power.

On the one hand, Yasukuni represents the need for the past to be subsumed within the larger narrative of suffering — both for the nation as well as for Asia in general—such that it constructs Japan's remorse within and reluctance without for the past (mis)deeds (see Iriye, 1991: Epilogue). On the other hand, once Tokyo's gaze turns on to Asia, the perceived difficulty of convincing Japan's peaceful intentions in Yasukuni becomes reified into an intersubjectivity that alter-casts Japan's neighbours as having malign intentions instead of legitimate concerns (Kim, 1995: Chap. 3). This is the dynamic through which Yasukuni becomes representative of Japan's difficult diplomacy with its Asian neighbours despite changes in Japanese leadership (The Economist, 7 October 2006: 29-31). 
The reiterated reconstruction of this Asia imaginary reproduces a shared sense of entrenchment in which the exchange of invectives between Japan and its neighbours is bound to be permanent (see Yoshida, 1995). Thus, Yasukuni has been elaborated into a symbol of awkwardness in Japan's Asian existence. The more criticisms there are over the politics of memory, the more Japan becomes introverted, subsequently de-legitimising Asian memories of suffering. This is the dynamic behind the official reification of 'difficulty' as the defining element of Japan's Asia diplomacy, as well as the symbolism inherent in Yasukuni.

\section{The Social Construction of Japan's Asia Relations}

Domestically, Yasukuni captures the imagination of both the political Right and the Left. The Right sees it as homage to the myth of Asian liberation. As The Economist(19 August 2006: 10) notes, the museum adjacent to the Shrine 'paints Japan in its wars of 1937-45 as the liberator of Asia, a victim of Western belligerency'. The Left, on the other hand, sees it as a manifestation of an unfettered glorification of militarism under which many innocent people perished (see Toyama et al, 1959). On its own, Yasukuni seems like a quintessentially domestic matter. The upheaval marks the culmination of Japan's ritualised soul-searching every summer starting with the commemoration on June 23 to mark the end of fighting in Okinawa, to the national remembrance day on August 15. The familiar narrativisation of the 'past' entails remembering the trauma of War: the carpet bombings of cities; Hiroshima and Nagasaki; escaping the Soviet incursion into Manchuria, to mention just a few. This ethnocentric ritual prioritises Japanese sufferings whilst those of Asian neighbours are neutralised. Any diplomatic fallout from Yasukuni is depicted as an intervention into Japan's domestic affairs, rather than a debate over the shrine's international significance. It is not surprising, therefore, that the United States has not commented on this issue, preferring to defer to Japan, China, and South Korea. As Daiki Shibuichi (2005: 208) argues, '[b]y keeping silent, the American government probably intends to avoid antagonizing the Japanese right, including its conservative politicians [who support the military alliance]'. Denny Roy (2005: 204) suggests that China's alarm over Yasukuni '[has] reaffirmed the Japanese view of China as excessively and 
disturbingly hostile toward Japan’. Similarly, Kim Yeong-seul (1995: 36) identifies South Korean obsession with the colonial past clashing with Japan's purported whitewashing of history propagating the vicious circle of invectives across the Tsushima Straits. Maruyama (1964: 157) argues that Japanese nationalism entails a 'zero-sum worldview' whereby either Japan convinces Asian Others of its legitimate position or feels that its national pride is dented, compelling it to resurrect honour and dignity at any price. Once Yasukuni re-emerges as a signifier of Japanese identity, Japanese domestic struggles are confounded by diplomatic name-calling through which the ‘difficulty’ of placating both Beijing and Seoul emerges as a reified social reality for Tokyo.

\section{Difficulty as Social Reality}

The sense of 'difficulty' arises from the perceived near impossibility of persuading Asia of its 'benign' intentions behind Yasukuni. For Japanese policy makers, Yasukuni is very much part of remembering the trauma of the War, not just the 'imperial glory', as some conservative fringe groups would like to portray it. From their perspective, China's reaction to Yasukuni is almost always a foregone conclusion: furore over Yasukuni is a ploy by the Chinese Communist Party (CCP) to maintain its legitimacy in light of a restive population. Okazaki Haruhiko, a rightwing commentator close to the then-Chief Cabinet Secretary, Abe Shinzo, parallels the government's scepticism towards China. He says that 'China's biggest aim in diplomacy towards Japan [is to drive] a wedge between the US and Japan. So Japan's diplomacy is obvious; to strengthen the US-Japan alliance. That's our China policy' (quoted in Financial Times, 24 August 2006: 6). While not necessarily representing the view of the Japanese government, Chiba Akira, the assistant press secretary in the Ministry of Foreign Affairs (MOFA), told a Chinese historian, Lanxin Xiang, that the 'Chinese government is looking for a scapegoat in order to maintain domestic unity' (Chiba and Xiang, 2005: 217); and that CCP's tendency to 'humiliate Japan [represents] a catharsis for China's own trauma' (216). Even when Yasukuni poses a domestic dilemma over how the nation should commemorate the past, it also symbolises Japan's sense of victimhood and suffering-so much so that the constant 
criticism solidifies negative images of Asian neighbours providing further relevance to the notion that 'Japan has apologised for the war on many occasions ... but the neighbours will never be satisfied' (The Economist, 8 October 2005: 15).

Tokyo's repeated encounters with both Beijing and Seoul congeals an impression within the policy circles that the neighbours are not satisfied with Japan's apologies and reassurances, simply because they can never be convinced of its pacifist intentions. Chiba (Chiba and Xiang, 2005: 218) captures the mood well. He writes that the 'Chinese should admit that Japan had apologised, even if they think that the Japanese are sorry for themselves’. Kim Yeung-seul (1995: 88) posits that Japan does have sympathies towards the Korean version of history; but once the Koreans start insisting on righting the past wrongs, it backfires by encouraging Japan to focus on Korean failings on the eve of Annexation in 1910. The flip-side of these arguments is the recognition within Japanese elite circles that neither China nor South Korea is ready to countenance Japanese side of the story. Herein lies the Self/Other dichotomy within the politics of memory: Tokyo officially remembers the 'past' as a traumatic experience with Yasukuni occupying a controversial, yet integral, part of the symbolism; while the Asian Other is perceived as unwilling to legitimise Japanese contrition.

Yasukuni, therefore, constitutes a double movement for Japanese identity construction. On the one hand, it is a source of domestic political debate between the Right and Left. It is a locus of struggle from which Japanese memory emerges and is elaborated. On the other hand, the domestic debate is almost immunised from external criticism by virtue of trivialising the memories of sufferings in Asia as a result of the ethnocentric mnemonics. In other words, the internal debate is constructed through expunging Asian Otherness to the extent that any interjection from China and South Korea is interpreted as an external interference into Japanese identity construction.

\section{Persistence of the Past as Reality in Northeast Asia}

Persistence of the past is a recurring theme in Japan's diplomatic relations with its most immediate neighbours; and even if relations do improve every now and then, there is a constant reminder that the politics of memory is omnipresent: '[e]very few 
months, Japan comes under pressure to offer a "proper” apology for its conduct during some of the bloodier parts of $\left[20^{\text {th }}\right]$ century' (The Economist, 5 December 1998: 22). This was prominent in 1998 when the then-president of South Korea, Kim Dae-jung, visited Tokyo, sending out conciliatory message to his hosts that the past should not dictate the future of Japan-South Korea relations (Tamaki, 2004). Two months later, the then-president of China, Jiang Zemin, also visited Japan, this time calling on the Japanese government to apologise for the past. The Economist (5 December 1998: 82) reported that,

Broaching another touchy topic during his official visit, the first by a Chinese head of state to Japan, Mr Jiang spoke frequently of Japan's aggression against China before and during the second world war. Japan's prime miminster, Keizo Obuchi, uttered an apology along the lines of those offered to other countries. But the leaders failed to agree on the written apology that seemed to be in the offing just prior to the visit. This gave rise to yet another semantic quandary: does the apology really count if it is only oral?

The 'feel-good' factor delivered by the Kim visit contrasts with the prickliness of Jiang's demands.

The almost incommensurable narratives of the past between Japan and its neighbours act as further impetus for the emergence and elaboration of difficulty into a social reality of diplomacy in Northeast Asia. ${ }^{6}$ Iriye Akira (1991: 214) suggests that, 'in order for Japan to forge a new era of globalisation, it needs to admit to its colonial past'. While his prognosis may be correct, Tokyo's reluctance to do so derives from its post-war identity as a 'peaceful state' (heiwa kokka) as a function of its remembering/forgetting; and its associated worldview reconstructing the negative images of Chinese- and Korean Others depicts an admission of past wrongs as a zerosum game. In other words, for Tokyo to become fully responsible to the memories of sufferings shared by the Asian Others translates into denying the legitimacy of Japanese Self.

\section{Yasukuni and the Politics of Emergent Collective Identity}

The Yasukuni controversy seems to the outside world as an example of Tokyo's dithering over its wartime memory. Looking in, however, reveals that it is a political 
product whereby the establishment dominated by the conservatives have effectively catapulted their version of memory as a dominant narrative that is exposed to the outside world. The emotiveness of Yasukuni is a reflection of the national discord between the Right and Left in which the Right dominates. As Shibuichi (2005: 199) notes, '[t]he contemporary Japanese rightists perceive the Yasukuni Shrine as a heartwarming symbol of self-sacrifice and patriotism', whereas the Left 'maintain that the shrine is a symbol of cruel militarism and scoff at the notion that it honors the “spirits of fallen heroes”'(ibid: 203). Superficially, the pilgrimage betrays a chasm between the two political camps. It also signifies a nation uncertain of Yasukuni's role in its memory construction. The politics of memory vis-à-vis Yasukuni is a platform upon which Japanese Self is contrasted to the Asian Otherness. ${ }^{7}$ The shrine's position as a locus of contestation reveals not only the domestic debate over how the past should be remembered, but also how the dominant discourse of Japanese collective identity as a function of the way the nation remembers the past is discursively represented.

\section{Yasukuni as Remembering}

As noted earlier, Japan's official memories of suffering are rife. The spectre of death inherent in it is symbolised through pilgrimage to Yasukuni. The official perception of the controversy is not whether the war-dead should be revered or not; but rather how they should be remembered. Hence, the discussion revolves around how a 'peaceful state' should honour its war-dead. As Koichi Nakano (1998: 510) argues,

While the claim that Japan is a unique nation is plainly not a new development of the 1990s, notable among the post-war additions to this list [of uniqueness identity] are the 'pacifist' constitution and Japan's status as the world's only hibaku koku (nation which suffered from atom bombs).

Ozawa Ichiro (1995: 480-81), a conservative MP, also wrote back in 1993 that,

There are no 'just' or 'unjust' wars: they are all the same, resulting in the deaths of so many people. Our military role in the world is to work under the aegis of the United Nations flag. This is the principle outlined in the Constitution, and the only way for us to survive. 
Put differently, the government's urge to pursue future-oriented diplomacy (miraishiko gaiko) through peaceful means is another way of addressing the trauma of war.

The memories of suffering are crucial ingredients in the discourse of peaceful identity; and Yasukuni acts as a forum for its expression. For instance, Emperor Hirohito has been a regular visitor to the shrine until 1975. In a new revelation in a memoir by the former Director of the Imperial Household Agency, Tomita Asahiko, Hirohito is said to have shown his distaste for Yasukuni visit, not due to its commemoration of imperialism, per se, but for honouring Class A war criminals. Tomita quotes Hirohito as saying,

[The statement in April 1988 regarding his 'opinions' of the War] I wanted to express my distaste for the wartime experience. I wanted to say how grateful I have been to the nation [kokumin] for their efforts in the post-war reconstruction....I am dismayed by the enshrinement of Class A war criminals....[The father of Yasukuni's chief priest] had strong regard for peace, but the son is oblivious to that. That is why I have not visited Yasukuni [since 1975] (Nihon keizai shimbun, 21 July 2006: 33).

Hosaka Masayasu (2006: 140) notes that the public debate over the enshrinement of Class A war criminals in Yasukuni was left ambiguous. Enshrinement was made possible precisely due to the existence of the conservative establishment-including the pressure groups (ibid: 143) — in 1975, to the dismay of Hirohito. While a detailed analysis of the circumstances around-and the ensuing debate about-the enshrinement is beyond the particular scope of this article, it needs emphasising that whatever the merits of the 1975 decision, today the Class A war criminals are there; and that the dominant narratives take into account this fact, and the resultant exchange of invectives is a 'reality' that the government faces. Moreover, three decades later, a public opinion poll conducted by the Nihon keizai shimbun in June 2005 showed 38 per cent in favour of prime ministerial pilgrimage, compared to 42 per cent against; but due to a spate of anti-Japanese demonstrations in China in April 2005, the August 2005 poll revealed 46 per cent in favour and 38 per cent in opposition. ${ }^{8}$ However much the enshrinement was conducted away from the public gaze (Hosaka, 2006: 144), Asian criticisms continues to galvanise public opinion in endorsing the official narratives of Yasukuni as a language of peace and remorse. Herein lies the potency of 
Yasukuni as a political project appropriating the dominant discourse of Japanese identity. ${ }^{9}$

\section{Yasukuni as a Conflation of Suffering}

The conflation of Asian sufferings into a generalised trauma in which Japanese experience is prioritised is one way of officially 'admitting' that wrongs have been committed in the nation's colonial past. Yet, once the conflation of sufferings is complete, Asia is forgotten; and the peace state identity provides a comfortable refuge into which war responsibility is ensconced. Put differently, the moment the gaze turns on Japan's responsibilities to Asian memories, the peace state identity ameliorates the unpalatable after-taste. ${ }^{10}$ While it is tempting to consider the remembering/forgetting dichotomy as representative of Japan’s collective amnesia (see Bruma, 1994; Hicks, 1997), the conflation acts as a device with which the past mistakes are enlisted in an effort at embarking upon its newly reformulated identity. As such, Yasukuni becomes both a vehicle through which Japanese post-war identity is represented and a locus within which the Asia imaginary is reproduced. Thus, the controversy over the shrine seems, on the surface, to divide the nation along the lines of the Right and Left (Shibuichi, 2005); but the dispute itself provides a discursive sphere within which the conflation of sufferings by the Japanese Self and Asian Others emerge; and Japan's future-oriented diplomacy (mirai-shiko gaiko) elaborated (Tamaki, 2004).

Once the conflation is complete, Yasukuni ceases to be an issue in which Japan's legitimacy in the international community is at stake. Rather, it becomes a domestic source of conflict questioning the 'correct' way of remembering the past. The debate centres on 'how' - rather than 'whether'-Yasukuni should enshrine the war-dead; and diplomatically, how the neighbours are to be placated. The corollary of this is to represent Chinese and Korean criticisms as interventions rather than legitimate concerns. Herein lies the source of 'difficulty' as a reified diplomatic reality for Tokyo.

Yasukuni as Forgetting 
The memories of suffering represented through Yasukuni effectively neutralises the sufferings of Asians under Japanese colonialism. The dominant political discourse of Japanese memory construction seems to elide Asian sufferings by conflating them into the general scourge of war. Thus, when atoning for the war, the recompense is directed at both the Japanese, as well as Asian, war-dead. But the prioritisation of Japanese victimhood contributes to an impression that Asia is forgotten. This provides for a vicious exchange of invectives between Japan and its neighbours: (1) Japan's peace state identity is elaborated on this remembering/forgetting dichotomy; and (2) Asian criticisms are dismissed by Japan's policy makers as a ploy to delegitimise Japan’s memory and peace state identity. As Reinhard Drifte (1998: 163) notes,

Younger Japanese leaders in particular are becoming impatient with a lack of political legitimacy of their country, which denies them what they consider Japan's natural leadership role in Asia. Having to accept a low profile and take international initiatives by stealth or with the help of other countries only because of Japan's historical legacy is increasing the frustration with Asia, although by refusing to acknowledge the past they continue to maintain this vicious circle.

To the effect that national remembering fails to fully accommodate the memories of suffering by the Others, this vicious circle is reproduced. Dower (1999: 25) argues that the war had 'left an indelible mark' on the Japanese psyche, further suggesting that the change in nomenclature from the Great Far Eastern War (Dai toa senso) to Pacific War (Taiheiyo senso) was 'such a maladroit rectification of names [such that it] facilitated the process of forgetting what they had done to the Asian neighbours' (419).

The primacy of Japanese suffering and death symbolised through Yasukuni makes this forgetting more palatable. Kajiyama Seiroku (1999: 162), a former MP and Chief Cabinet Secretary, argues that 'we must never forget the mistakes of history', while at the same time suggesting that 'our duty is to destroy negative legacies and build a new foundation [for national security]' (173). Thus, in calling for a more assertive role in the international community, Kajiyama's narratives exhibit the dynamics of remembering/forgetting dichotomy. Even the so-called Murayama Remark of August 1995-in which the then prime minister, Murayama Tomiichi, 
'admitted' to Japan's war guilt-inheres a hint of remembering/forgetting. In the Remark issued on August 15 he noted that Japan had made mistakes in its policies by colonising Asia, thereby inflicting pain on the Asian people. He then went on to say that Japan should do away with its 'narrow nationalism' (dokuzen-teki na nashonarizumu) and actively promote peace and democracy (Asahi shimbun, 16 August 1995: 1). Here, the admission of war-guilt cohabitates with the desire to move

on. Moreover, the ethics of responsibility towards the memories of suffering by Asians is lacking. The former director of Foreign Ministry’s Economic Bureau, Ogura Kazuo (1993: 72), writes too, that 'Japan must learn the lessons of history; but Asia must not be held captive by it either'

Thus, the peace state identity represented through Yasukuni is constituted through the force of forgetfulness towards the Asian Others. Nagumo Kazuo (1994: 68) summarises the sentiment well. He argues that the reluctance of policy makers to posit war guilt stifles national debate. The absence of such collective soul-searching encourages the public to support a more assertive role for Japan; as well as to make it less awkward for the nation to glorify colonial history. Admission of a particular segment of history, coupled with a call for more assertive role in line with its peace state identity, points to the inherent resolution of the remembering/forgetting dichotomy in the form of Yasukuni as an official symbol of suffering.

\section{The Many Uses of Yasukuni as Japanese Identity Representation}

Yasukuni as an issue remains unresolved, and the domestic debate often stops at the water's edge. Nor does it problematise the ethic of remembering/forgetting. Instead, it concentrates mainly on the Constitutionality of official visits, as well as its diplomatic impact without an introspection into the dynamics behind the construction of difficulty vis-à-vis China and South Korea.

The domestic negotiations over Yasukuni-as-identity-representation expose the contemporary infrastructure of Japan's official Asia imaginary. Shibuichi (2005: 213) states that, 
Domestically, there have been attempts to resolve the Yasukuni Shrine dispute by establishing an alternative to the shrine where people could pay their respects to the war dead, or by forcing the shrine administration to de-shrine the class-A war criminals by removing their spirits from the shrine.

The legitimacy of Tokyo Trials and the designation of Class-A war-criminals are often the topic of a heated debate (see Dower, 1999: Minear, 1972); but its tone is usually self-centred, as if the sufferings in Asia were an after-thought. Yoshida Hiroshi (1995: 228-29) suggests that the familiar refrain of 'regrets' and 'apologies' from Tokyo are counter-balanced by 'justifications' for the war and colonialism in general, to the effect that the Japanese admission of guilt constitutes a mere diplomatic ploy to appease the neighbours. This Japanese narrative construction signifies a lack of an in-depth soul-searching, failing to nurture an ethic of responsibility towards Asia as intrinsic to national memory construction. ${ }^{11}$

\section{Yasukuni as an 'Obligation'}

One way in which the trauma is remembered and represented is by recasting Yasukuni as a national 'obligation'. This centres on the notion that the nation as a whole needs to pay tribute to the war-dead. This is of particular import to the Right. Shibuichi argues that the conservatives 'feel the shrine symbolises the "history of modern Japan and the hardships it has endured”' (Sankei shimbun quoted in Shibuichi, 2005: 199-200). For them, the condemnation of the war is tantamount to a condemnation of Japan's modern history (ibid), to the extent that they 'fear that an admission of guilt for past transgressions would turn their erstwhile fathers and brothers into war criminals' (ibid: 200). This sentiment reverberates throughout the policy circles. The former MP-and current Governor of Tokyo-Ishihara Shintaro (1991: 96) wrote back in 1991 that,

It is true that Japan has committed significant inconvenience (tadai na meiwaku) on those who were colonised, but it must also be remembered that Japan as the only coloured nation (yushoku jinshu) was a member of the Great Powers, and to that extent the US, the United Kingdom, France and others are guilty of similar crimes. At the same time, as former third world leaders such as Nasser and Sukarno have said, it must be recognised that Japan's 
involvement in the Second World War led to the liberation of all [sic] colonies (subeteno shokuminchi no kaiho).

By implication, Ishihara's assessment of Japan's past deeds depicts the War and its imperial experience as a fait accompli in a pre-war balance of power system. This makes it more palatable for the war-dead to be honoured and inoculates Yasukuni visit as a 'moral' deed.

This imaginary forms the backdrop for Koizumi's justification for his pilgrimage. It must be remembered that Koizumi did not glorify war. Instead, he believed the war to have been a mistake, and it is within this context that his visits and arguments need to be interpreted. In April 2002, he argued that the rationale for his visit then was 'to sincerely mourn those who gave their lives to the country, separated from their family against their will' (quoted in Financial Times, 22 April 2002: 26). So, while the Financial Times (15 August 2006: 4) states that 'Mr Koizumi is unrepentant, saying his visits are to pray for peace', what he is 'unrepentant' for is not the War, but the visit itself. The Economist (18 August 2006: 10), on the other hand, is cautious, noting that 'Mr Koizumi is no diehard imperialist. He sees the war dead as victims of Japan's own militarism'. Koizumi's Yasukuni pilgrimage is a prime example of how the establishment faces the irrefutable history of militarism.

A more moderate member of the LDP, Kato Koichi, warns that 'this kind of nationalism is very hard to calm down once leaders ignite it. This is a dangerous nationalism. Politicians should not try to use it' (quoted in Financial Times, 28 August 2006: 5). Newspaper editorials reflect this official debate. The conservative Yomiuri shimbun argues that an 'alternative needs to be sought', while suggesting that Yasukuni is one manifestation of a national obligation. ${ }^{12}$ More rightwing Sankei shimbun calls for the shrine to remain a tranquil place 'where the nation can solemnly calm the spirits of war-dead'. ${ }^{13}$ Hence, the difference within the conservative mainstream is over 'how' the nation should mourn the loss, but there is a tacit agreement that the act of remembering is a national obligation. Koizumi himself reflects this, arguing, 'what is wrong with mourning the war-dead?' ${ }^{14}$ adding, 'we owe our existence to those who perished'. ${ }^{15}$ Replying to questions from news reporters, 'I am in no way justifying the war. On the contrary, we must never wage war again. Nor must we forget those who perished'. ${ }^{16}$ 


\section{Yasukuni as Japan’s History}

The corollary to Yasukuni as a national obligation is the notion that the shrine represents a quintessentially Japanese history. The pilgrimage is a duty precisely because what is recalled is the nation's struggle with the West in the $19^{\text {th }}$ and early $20^{\text {th }}$ centuries culminating in the sufferings during the War.But this is to say precious little of the sufferings on the Asian continent, apart from the ritualised apologies interspersed with denials. Put differently, the Japanese Self's remembrance of the past necessarily interpenetrates the history of Asian Others to the effect that the claim that Yasukuni is solely a Japanese memory representation becomes highly political.

One repercussion of the international criticisms directed against Japan is a nationalist backlash which posits that both China and South Korea have no business reminding Japan how it should remember its past. The exchange of invectives becomes increasingly caustic, as Tokyo's remembrance of its memory as a 'victim' is constituted in large part in the forgetting of the sufferings of the Asian Others. Japan's post-war peace state (heiwa kokka) identity ${ }^{17}$ justifies the self-centred memorial as a legitimate commemoration of the nation's suffering, both at the hands of the military clique and the Realpolitik. Within this context, Yasukuni provides a forum upon which the aggression is neutralised and aggregated into a general suffering that everyone experienced in the War. While holding the pre-war military to account, the trauma is depicted as a lesson from which Japan's resolve to preserve its peace state identity is reaffirmed. As the Speaker of the Lower House, Kono Yoichiro, argued at the National Remembrance Ceremony on 15 August 2006, 'when we look back and mourn those young, talented, souls who perished dreaming of a better Japan, we must never leave the responsibilities of military leaders ambiguous'. ${ }^{18}$ Hence, both the sufferings and the mistakes of militarism are conflated into a past from which a new and peaceful Japan emerged. To this extent, Yasukuni is not necessarily a fond memory, but rather a trauma that is ingrained in the government's historical narrative and becomes an obligation for the current generation. It is a monument to nation's soul-searching to the extent that external criticisms are depicted as a rejection of Japan's own memory of suffering, as well as a denial of its peace state identity. 
Kono's argument that the military clique should be held responsible for the sufferings caused during the war is a familiar theme. This, after all, is one of the reasons why the domestic politics of Yasukuni is often contentious (see Shibuichi, 2005: 203-4). The dominant discourse of memory reflected in Koizumi's adamant refusal to countenance domestic critics also depicts the pre-war military as responsible, and that he in no way sought to condone their acts of violence. However, it is also the case that the narrative construction of memory disaggregates their wrongs from the national suffering during the War in general, to reconstruct the trauma as a uniquely Japanese memory. When asked about Class A war-criminals on 15 August 2006, Koizumi commented that, 'they are convicted as Class A warcriminals because they were responsible for the War. They even admit to it. But [my homage] has nothing to do with paying tribute to them in particular. I am mourning for everyone who lost their lives' ${ }^{19}$ Furthermore, in response to suggestions that the timing of the visit might agitate critics both from within and without, he replied, 'it does not matter when I go. There are forces that criticise me anyway. So I decided today [August 15] as most appropriate'. ${ }^{20}$ Inherent within his answer is that the commemoration for Japan's involvement in the war is a matter for the Japanese nation to undertake. To this end, Koizumi argued that, 'a Japanese prime minister pays tribute to a Japanese facility. Then he prays there. Then foreign governments criticise me for doing so. I do not think that is appropriate'. ${ }^{21}$ Prior to this on 10 August 2006, Koizumi stated that, 'I see no reason why I should be criticised for visiting any facility', 22 and Financial Times (15 August 2006: 4) reports that, 'he says foreigners have no business telling Japan how it should honour its fallen'.

To be sure, Koizumi's narratives occupy one corner of the dominant discourse; and that there are critics who criticise his adamance. Watanabe Tsuneo, the owner of the largest-circulation conservative newspaper in Japan, Yomiuri shimbun, argues that,

Mr Koizumi worships at a shrine that glorifies militarism. This person Koizumi doesn't know history or philosophy doesn't study, doesn't have any culture. That's why he says stupid things like, 'what's wrong about worshipping at Yasukuni?' Or 'China and Korea are the only countries that criticise Yasukuni.' This stems from his ignorance (quoted in The Economist, 18 February 2006: 64). 
Watanabe's 'realisation' that Japanese memory impacts on its relations with China and South Korea coexists with the calls to 'normalise' the country. 'Normalisation' entails a closure on the debate about Yasukuni and war criminals, as well as for Japan to exercise enhanced confidence in projecting military power abroad within the realm of collective security — a project championed by the then-Cabinet Secretary Abe. This entails an assumption that Japan's past is for Japanese people to decide and eventually resolve, paving the way for a consensus on how the nation projects its image abroad. Okazaki suggests that '[t]here's good nationalism and bad nationalism. If you raise the flag and sing the national anthem, that's good nationalism. But if you tear down the flag of another nation, that's bad nationalism' (quoted in Financial Times, 28 August 2006: 5). This is the vicious circle whereby more prodding from the Asian Others encourages the consolidation of narratives within Japan.

A perusal of newspaper editorials for 16 August 2006 shows a trend in which various views confirm the official narrative. ${ }^{23}$ Starting from the left, Asahi shimbun warns of 'narrow nationalism' which potentially neutralises the deeds of wartime leaders. It suggests that 'it is insufficient [for the nation] to be told by others of this obvious fact', though the newspaper is short on analysis with respect to the kinds of critique both from within and without the country. ${ }^{24}$ To this extent, Mainichi shimbun criticises Koizumi's lack of interest in persuading both the domestic and foreign public opinion over why the visit needs to be seen as sincere and not a historical whitewash. ${ }^{25}$ Nihon keizai shimbun urges calm introspection, calling on the readers to reflect on what the War actually meant. ${ }^{26}$ Yomiuri shimbun distinguishes itself by focusing on the international dimensions of the visit. It says that 'it is insufficient to suggest that [Yasukuni] is an issue of the heart (kokoro no mondai). It needs to be seen within the larger context of Asian diplomacy'. ${ }^{27}$ The archconservative Sankei shimbun remains adamant that the visit was a right thing to do. It argues that, 'despite interventions by China and South Korea, Prime Minister Koizumi has been steadfast in how domestic mourning should be separated from diplomatic posturing, ${ }^{28}$ With the exception of Yomiuri, the newspapers are aware of the controversy but seem unable to delve into the 'inner logic' within the emergence of such sensitivities. Furthermore, the editorials in general seem to take for granted that Yasukuni is a peculiarly Japanese way of remembering the past; and what is at stake diplomatically is how to persuade the neighbours of Japan's goodwill. 
This seeming lack of realisation that there are overlaps between and among the histories of Japan, China, and Korea provides a fertile ground for the conservative narratives to dominate the public debate. Ishihara (1991: 97) argues that, 'using Tokyo Trial—highly questionable in itself_as a weapon in criticising Japan's war record is tantamount to Chinese propaganda'. Shibuichi (2005: 202-3) notes that,

many rightist intellectuals do recognise Japan's wartime atrocities as a historical fact. They face the dilemma of reconciling the atrocities with the desire to stress the brighter side of Japan's modern history and their wish to propagate inspiring stories of the hardships the ancestors faced during Meiji and afterward.

The Right depicts any gaze on the sufferings of Asian Other as a history of 'selfflagellation’ (jigyaku-shikan). According to Takahashi Tetsuya (1999: 112-13), 'the reason why "textbooks" are crucial is because [the rightwing intellectuals] seek to regain national “dignity” by expunging “self-flagellating” history.' He argues that the only recourse to normalisation lies in the recognition of an ethic of responsibility towards the memories of suffering by the Asian Others (130). The flip-side of this is to say that the seeming lack of consensus over Yasukuni in fact represents a process of forgetting Asia as an integral part of remembering one's own sufferings. Yoshida (1995: 223) goes on to argue that war responsibility has become a taboo; and that ambivalence in the commemoration has acquired a life of its own (224-29).

The Left, too, is guilty of forgetting. Masao Miyoshi (1991: 155) argues that,

In fact, at no time during the period of protest in 1960 did the agitation [by the Left] spread outside the limited bourgeois opposition to the program of remilitarisation under US patronage. The minority problems, the working conditions of the poor, and Japan's war atrocities in Asia-in Korea, for instance, or even in Okinawa-were all excluded from the focus of the struggle.

John Dower (1999: 27) interprets the national ambivalence in a similar manner. He suggests that Asia played 'no significant role...they became invisible' in how Japan remembers its past, to the extent that 'the crimes that had been committed against Asian peoples through colonization as well as war were all the more easily put out of mind'. It seems that both the Right and Left are preoccupied with locating Yasukuni at the centre of a domestic debate, thereby delegitimising Asia's claims to their 
memories of sufferings. This is made easier by the common scapegoat-the pre-war military clique.

\section{Yasukuni as a Symbol of Anti-Japanese Sentiments}

Tokyo's de-legitimisation of Asian memories entails a double-movement: on the one hand, the Japanese sufferings are seen as deserving recognition; while, on the other hand, the Chinese and Korean claim to have suffered under Japanese imperialism are characterised as subversive. This results in Japanese policy entrepreneurs seeing Yasukuni as a reflection of anti-Japanese sentiments. This interpretation has been particularly pronounced during the spate of anti-Japanese demonstrations in China in April 2005. The Economist ('A Survey of Japan’, 8 October 2005: 15) observes that,

the [Chinese] protests about the shrine and about the small number of Japanese history textbooks that whitewash the country's war conduct now seem to strike more Japanese as unfair. Japan has apologised for the war on many occasions, runs the argument, but the neighbours will never be satisfied.

Various newspaper editorials from 15 August 2005 reiterate the predominant view. Sankei shimbun (15 August 2005: 2) praises Japanese people for their 'calm observation' of Chinese protests. It claims that the people 'know that anti-Japanese demonstrations were used as a propaganda tool to prevent Japan from becoming a permanent member of the United Nations Security Council'. Yomiuri shimbun (15 August 2005: 3), on the other hand, simply states that Yasukuni has become a 'diplomatic issue as well', while the centrist Mainichi shimbun (15 August 2005: 2) airs its concern over Yasukuni emerging to become a perennial source of SinoJapanese dispute. It criticises Koizumi, arguing that he 'should know better' than 'encouraging low-level nationalisms which are counter-productive'. Nihon keizai shimbun (Nikkei) (15 August 2005: 2) notes that Koizumi’s visit to the shrine helped to degenerate Japan's relations with both China and South Korea. It says, 'we do not agree to Chinese and Korean ploy to bring up the issue of history at every turn, but it is also the case that so long as Japan's treatment of the past remains ambiguous, Japan's relations with its neighbours are apt to remain difficult'. Following the spate 
of demonstrations, Asahi shimbun (15 August 2005: 1) remains critical of China, noting on its front-page editorial that,

Anti-Japanese sentiments are a source of frustration for Japan. This is a result of a vicious circle of nationalisms.... [The rising tide of] Japanese nationalism is understandable, given the constant calls for apologies for the past fifty years. On top of that, China as well as North Korea have developed, or are in the process of developing, nuclear weapons. The Japanese people have been fed up with being branded as aggressors. With the issue of North Korean kidnappings, we are starting to feel as though we are the victims.

Hence, save for Nikkei, the newspaper editorials depict anti-Japanese sentiments and constant calls for apology as a fixture in Tokyo’s diplomatic relations. Nagumo Kazuo (1994: 66) argues that Japanese opinion leaders 'do not question why [the issues of the past] are so problematic.... They blame "anti-Japanese" Japanese (hanNichi Nipponjin) and mass media for turning the issue into a diplomatic problem'. While the media exogenises the sources of difficulty and the policy elites hold media accountable, there is no mention of Asia's mnemonics of suffering.

The Minister of Economy, Trade, and Industry, Tanigaki Sadakazu, warns that, 'if the situation is left unattended, there's a possibility of severe damage to our national interest. We need to think seriously about how to live together with our Asian neighbours' (quoted in Financial Times, 24 August 2006: 6). It is noteworthy that even Tanigaki's narrative externalises the source of conflict as coming solely from China's hyper-sensitivities. Koizumi reiterates the sentiment when he claims that, 'my opponents are suggesting I should not do things that China finds offensive. Do I have to listen to everything China says?' ${ }^{29}$ Furthermore, he states that, 'my detractors say that if I listen to China and South Korea, Asian diplomacy will improve. I do not think so'; and with respect to Beijing's postponement of meeting between the heads of government, he argues that, 'I am willing to attend one. But I am not the one who is reluctant'. ${ }^{30}$ Herein lies the potency of Yasukuni as a symbol of external pressure.

Yoshida (1995: 7) captures the national sentiment well. He argues that the 'political narratives have failed to reconcile admission of guilt with a clear-cut historicism', such that, an admission of guilt has degenerated into 'a mere means to win public opinion in Asia' (ibid). Hence, the discursive space of Yasukuni constitutes an ethnocentric sphere in which the legitimacy of mnemonics focuses primarily on the sufferings of Japanese Self in isolation from the international 
dimensions of modern Japanese history. Even if a domestic consensus is lacking on Yasukuni, an agreement has emerged in the process of this on-going project by tacitly delegitimising claims to sufferings by the Others. This is the prime locus upon which the politics of memory takes on an international dimension.

\section{Conclusion}

The Yasukuni controversies come and go. The ritualised national remembrance every August invites speculation as to whether or not the prime minister and his cabinet members will visit the shrine; and if so, in what capacity-official or personal. On the one hand, given the seasonal characteristics of the debate, it is easily dismissed as a national pastime, as well as an occasion when the nation is re-exposed to external criticisms from China and South Korea. On the other hand, its recurring nature also suggests that the controversy itself is very much an integral part of not only how the nation remembers the past, but how memory constitutes an important ingredient in the construction of a dominant historical narrative The existence of the debate itself is a testament to the dynamism within the process of emerging Asia imaginary through which the Japanese Self is contrasted in opposition to Asian Otherness. While the debate is often introspective, Japan's Asia imaginary provides a backdrop with which the legitimised national history is measured against the external, 'illegitimate', version. Governments of Japan, China, and South Korea have recently established a committee of historians to forge a more unified historical narrative, but the underlying politics of memory points to the difficulty of overcoming public sentiments in narrowing the gap between and among the various national histories. Put differently, the very need for such a consensus indicates the diverse and sensitive nature of the debate itself (see Yeung, 1997: Chap. 5; Takahashi, 1999: 18-54).

The Yasukuni debate is exactly that: it is a debate. This implies that there are conflicting views as to what the shrine means and how it should be positioned within the larger national psyche. Yet, in order for debates to take place, there needs to be a common platform upon which arguments must be tabled. Here, Yasukuni provides a fertile ground upon which Japanese identity is constantly contested and reconstructed. This process is a long drawn-out one; and whether Japan's memory construction takes 
on a different form in the future still needs to be seen. To the effect that the remembering/forgetting dichotomy is an integral part of the dominant discourse, external criticisms solely stressing Japanese atrocities instead of its mnemonics of suffering will only exacerbate the friction. Likewise, the difficulty of seeing beyond the narrow ethnocentricity of sufferings within the Japanese establishment is apt to do the same. So long as the ethic of responsibility towards the Other-and this can be said of both Japan and its neighbours-is seen as a 'concession' rather than a 'compromise', reconciliation remains a distant dream.

\section{Notes}

* Japanese names are presented in the traditional manner-family names followed by given names, except in cases where names of authors appear in western format.

${ }^{1}$ Asahi shimbun (Web edition), 10 August 2006.

<www.asahi.com/politics/update/0810/007.html>. Accessed on 10 August 2006.

${ }^{2}$ Asahi shimbun (Web edition), 29 September 2006.

<www.asahi.com/politics/update/0929/003.html>. Accessed 29 September 2006.

${ }^{3}$ Asahi shimbun (Web edition), 27 September 2006. <www.asahi.com/politics/update/0927/002.html>. Accessed 27 September 2006.

${ }^{4}$ I thank the anonymous reviewer for emphasising this point.

${ }^{5}$ See Archer (1996: Chap. 8) for theoretical discussion on emergence.

${ }^{6}$ For theoretical discussion on the reconstruction of intersubjectivity, see John Searle (1995); Margaret (1996); and Tamaki (2004).

${ }^{7}$ It is worth noting that while the Right justify their positions by blaming the pre-war military, the Left does likewise. As such, the participants in the national debate incriminate the military clique as the starting point. See for example Toyama et al (1995: 127-30).

12 Suzuoki Takashi (2006), 'Hajimatta bunri to dakyo: Kankoku to Nippon to’, Nihon keizai shimbun (Web edition), 18 August. $<$ www.nikkei.co.jp/neteye5/suzuoki/20060816n598g000_16.html>. Accessed 8 July 2008. 
13 I thank the anonymous review for pointing this out to me.

${ }^{14}$ See Murayama Remark of 15 August 1995; as well as Ogura (1991: 94110).

${ }^{15}$ Or, for that matter, this very forgetting and trivialisation can be construed as the Japanese ethic of responsibility. Either way, the inherent, 'political' nature of Yasukuni reveals the overall process of identity construction.

16 'Editorial', Yomiuri shimbun (Web edition), 16 August 2006. <www.yomiuri.co.jp/editorial/news/20060815ig90.thm>. Accessed, 15 August 2006.

17 'Editorial', Sankei shimbun, (Web edition), 16 August 2006. $<$ www.sankei.co.jp/news/editoria.htm>. Accessed, 15 August 2006.

18 Quoted in Asahi shimbun (Web edition), 15 August 2006. <www.asahi.com/politics/update/0815/004.html>. Accessed, 15 August 2006.

19 Quoted in Asahi shimbun (Web edition), 15 August 2006. <www.asahi.com/politics/update/0815/006.html>. Accessed, 15 August 2006.

20 Quoted in Nihon keizai shimbun, (Web edition), 15 August 2006. <www.nikkei.co.jp/seiji/syusyou.html>. Accessed, 15 August 2006.

21 For discussions on Japan's peace-state identity, see for example, Drifte (1998: 25-28),; and Katzenstein (1996: Chap. 5).

${ }^{22}$ Asahi shimbun (Web edition), 15 August 2006. <www. asahi.com/politics/update/0815/008.html>. Accessed 15 August 2006.

${ }^{23}$ Asahi shimbun (Web edition), 15 August 2006. <www.asahi.com/politics/update/0815/004.html>.Accessed 15 August 2006.

${ }^{24}$ Asahi shimbun (Web edition), 15 August 2006. <www.asahi.com/politics/update/0815/006.html>. Accessed 15 August 2006.

${ }^{25}$ Nihon keizai shimbun (Web edition), 15 August 2006. <www.nikkei.co.jp/seiji/syusyou.html>. Accessed 15 August 2006.

${ }^{26}$ Asahi shimbun (Web edition), 10 August 2006. <www.asahi.com/politics/update/0180/007.html>. Accessed 10 August 2006.

${ }^{27}$ Newspaper editorials on Koizumi’s visit to Yasukuni appears on August 16, the day after the actual visit, simply because the visit took place in mid-morning of August 15: editorials for August 15 betrays a familiar gamut of soul-searching in which they seek to set the agenda for the memorial day. The date of access for these editorials show August 15, but this is due to time difference. 
${ }^{28}$ Asahi shimbun (Web edition), 16 August 2006.

<www.asahi.com/paper/editorial.thml\#syasetu1>. Accessed 15 August 2006.

${ }^{29}$ Mainichi shimbun (Web edition), 16 August 2006. <www

mainichi.msn.co.jp/eye/shasetu/news/20060816k0000,070141000c.html>. Accessed 15 August 2006.

${ }^{30}$ Nihon keizai shimbun (Web edition), 16 August 2006.

<www.nikkei.co.jp/news/shasetsu/index20060814MS3M1400214082006.html>. Accessed 15 August 2006.

${ }^{31}$ Yomiuri shimbun (Web edition), 16 August 2006.

<www.yomiuri.co.jp/editorial/news/20060815ig90.htm>. Accessed 15 August 2006.

32 Sankei shimbun (Web edition), 16 August 2006.

<www.sankei.co.jp/news/editorial.htm>. Accessed 15 August 2006.

${ }^{33}$ Asahi shimbun (Web edition), 10 August 2006.

<www.asahi.com/politics/update/0810/007.html>. Accessed 10 August 2006.

${ }^{34}$ Nihon keizai shimbun (Web edition), 15 August 2006.

<www.nikkei.co.jp/seiji/syusyou.hmtl>. Accessed 15 August 2006.

\section{References}

Anderson, Benedict (1991), Imagined Communities. London: Verso.

Archer, Margaret S. (1996), Culture and Agency: The Place of Culture in Social Theory, Rev ed.. Cambridge: Cambridge University Press

(1995), Realist Social Theory: The Morphogenetic Approach. Cambridge: Cambridge University Press.

Booth, W. James (1999), 'Communities of Memory: On Identity, memory, and Debts’, American Political Science Review, 93:2, pp. 249-63.

Brubaker, Roger, and Frederick Cooper (2000). 'Beyond “identity”', Theory and Society, 29:1, pp. 1-47.

Bruma, Ian (1994), Wages of Guilt. London: Jonathan Cape. 
Chiba, Akira and Lanxin Xiang (2005), 'Traumatic Legacies in China and Japan: An Exchange’, Survival, 47:2 pp. 215-32.

Dower, John (1999). Embracing Defeat: Japan in the Aftermath of World War II. London: Allen Lane the Penguin Press.

Drifte, Reinhard (1998), Japan’s Foreign Policy. London: Macmillan.

Hicks, George (1997), Japan's War Memories: Amnesia or Concealment. Aldershot: Ashgate.

Hosaka Masayasu (2006), 'Yasukuni jinja to A-kyu senpan’, Sekai, September, pp. 139-46.

Iriye Akira (1991), Shin Nippon no gaiko. Tokyo: Chuko shinsho.

Ishihara Shintaro (1991), 'Nippon wo otoshi ireta joho kukan no kai', Bungei shunju, April, pp. 94-110.

Kajiyama Seiroku (1999), ‘Sokoku boei-ron’, Bungei shunju, June, pp.160-73.

Katzenstein, Peter J. (1996) Cultural Norms and National Security: Police and Military in Postwar Japan. Ithaca: Cornell University Press.

Kim Yeung-seul (1995), Nikkan kankei no sai-kochiku to Ajia. Fukuoka: Kyushu daigaku shuppan-kai.

Kosaka Masataka (1995), 'Genjitsu-shugi sha no heiw-ron' in Kitaoka (ed), Sengo Nippon gaiko-ron. Tokyo: Chuo-koron, pp. 207-24.

Maruyama Masao (1964), Gendai seiji no shiso to kodo. Tokyo: Miraisha. (1961), Nippon no shiso. Tokyo: Iwanami shinsho.

Minear, Richard H. (1971), Victors' Justice: The Tokyo War Crimes Trial. Tokyo: Tuttle.

Miyoshi, Masao (1991), Off Center: Power and Culture Relations Between Japan and the United States. Cambridge, MA: Harvard University Press.

Nagumo Kazuo (1994), 'Nitcho kankei-shi kenkyu no genjo ni tsuite: sakkon no “han-nichi ken-kan” ron wo fumaete’, Ajia Afurika kenkyu, 34:4, pp. 63-69.

Nakano, Koichi (1998), 'Nationalism and Localism in Japan’s Political Debate of the 1990s', The Pacific Review, 11:4 pp. 505-24.

Narvaez, Rafael F. (2006), 'Embodiment, Collective Memory and Time', Body \& Society, 12:3, p. 51-73 
Ogura Kazuo (1993), ““Ajia no fukken”, Chuo koron, July, pp. 60-73.

Olson, Mancur (1965) The Logic of Collective Action. Cambridge, MA: Harvard University Press.

Ozawa Ichiro (1995), 'Futsu no kuni ni nare', in Kitaoka Shinichi (ed), Sengo Nippon gaiko-ron shu. Tokyo: Chuo-koron, pp. 461-81.

Roy, Denny (2005), 'The Sources and Limits of Sino-Japanese Tensions', Survival, 47:2, pp. 191-214.

Searle, John (1995), The Construction of Social Reality. London: Penguin.

Shibuichi, Daiki (2005), 'The Yasukuni Shrine Dispute and the Politics of Identity in Japan: Why All the Fuss?', Asian Survey, 45:2, pp. 197-215.

Tamaki, Taku (2004), “Taking the 'Taken-for-Grantedness' Seriously: Problmatizing Japan's Perception of Japan-South Korea Relations,” International Relations of the Asia-Pacific, 4:1, pp. 147-69.

(2003), “Constructing 'Japan in Asia',” in Stephanie Lawson (ed), Europe and the Asia-Pacific: Culture, Identity, and Representations of Region. London: CurzonRoutledge, chapter 11.

Tanaka Akihiko (1997), Anzen hosho; sengo 50-nen no mosaku. Tokyo: Yomiuri shimbunsha.

Toyama Shigeki, Imai Seiichi, and Fujiwara Akira (1959), Showa-shi. Tokyo: Iwanami shinsho.

Ueno Terumasa (2005), “"Posuto-kozoshugi” to rekishi-gaku: “jugun-ianfu” mondai wo meguru Ueno Chizuko Yoshimi Yoshiaki no ronso wo sozai ni', Nipponshi kenkyu, No. 509, pp. 1-33.

Yamanouchi Masayuki (2005), 'Rekishi to gaiko: ukisugi no bohatei to shite', Gaiko Forum, August 2005, pp. 8-14.

Yeun Keun-cha (1997), Nippon kokumin-ron: kindai Nippon no aidentiti. Tokyo: Chikuma shobo.

Yoshida Yutaka (1995), Nippon-jin no senso-kan. Tokyo: Iwanami shoten. 